\title{
ДОГМАТ ПРЕСВЯТОЙ ТРОИЦЫ, ФИЛОСОФСКО-БОГОСЛОВСКИЕ СПОСОБЫ ЕГО ПОЗНАНИЯ И ИХ СЛЕДСТВИЯ
}

\begin{abstract}
Аннотация. В работе приводится философско-богословское познание основополагающего догмата Пресвятой Троицы. Показано, что использование методологии философии позволяет расширить границы познания и повысить его достоверность. Последнее позволяет произвести анализ достаточности источников оснований Православного Догматического богословия.

Показано, что наличие двух источников оснований: Священного Писания и Апостольского Священного Предания противоречит основополагающему Догмату Пресвятой Троищы. Источников оснований Догматического богословия должно быть три. Используя методологию принципа дополнительности, показано, что третьим источником оснований должна быть прямая речь (Слово) Иисуса Христа при его земной жизни. В качестве такого третьего источника могут быть использованы Нагорная проповедь и Евангелие от Фомы.
\end{abstract}

Ключевые слова: философия, богословие, догмат, Святая Троица, триединство, познание, методология, источники основания, Нагорная Проповедь, Евангелие от Фомы.

Слава Отцу и Сыну и Святаму Духу, и ныне и присно и во веки веков.

Аминъ.

Трисвятое

$\mathrm{B}$ Православном Догматическом богословии догмат Пресвятой Троицы (или догмат Троичности) имеет Высшую иерархию, так как на нем непосредственно основывается ряд других великих догматов Церкви, и, прежде всего, догмат нашего искупления (учение о спасении). Учение о Пресвятой Троице составляет содержание всех символов веры, какие употреблялись и употребляются в Православной Церкви, а также и всех частных исповеданий веры, написанных по разным случаям пастырями Церкви.

Вместе с тем, догмат о Пресвятой Троице из всех христианских догматов является самым трудным для его освоения ограниченной человеческой мыслью. Поэтому ни о какой иной христианской истине борьба в истории древней Церкви не была столь напряженной и драматичной, как об этом догмате и об истинах непосредственно с ним связанных. Каких только соображений не высказывалось как за, так и против догмата о Святой Троице! С одной стороны, возражения: «Бог един, и никаких лиц у Него быть не может»; или: «Аллах не нуждается в сотоварищах»; или: «первичных начал - не три, а два, например, инь и янь».

С другой стороны, выдвигались всевозможные «объяснения» тринитарного догмата с помощью логических триад: материя - энергия - форма; бытие - ничто - становление; бытие - познание - воля; добро - красота - истина; или триад психологических: чувство - мышление - интуиция; ум - мысль - слово; или антропологических аллегорий: отец - мать - сын; Дух Святой как ипостасная любовь Отца и Сына; Сын и Святой Дух как правая и левая рука Отца; наконец, отождествление со Святой Троицей каждой из бесчисленных триад языческих богов, начиная с индийского Тримурти. Иногда высказывается даже такая «супер-экуменическая» идея: каждая из трех мировых религий - ислам - христианство и буддизм - есть якобы путь преимущественного познания одного из Лиц Святой Троицы.

Приведенные примеры, при всей их неадекватности, уже намекают на богатство возможностей, скрытых в тринитарном догмате. В то же время, очевидна опасность профанации этого величайшего достижения человеческого духа на пути богопознания. 


\section{Философия и культура 4(64) • 2013}

С одной стороны, тринитарный догмат абсолютно персоналистичен, поэтому никакая безличная триада не может быть совершенным образом Святой Троицы. Святая Троица есть не «что», а «Кто»; и это же относится к каждому из Лиц (Ипостасей). С другой стороны, Три Лица имеют единую природу, единую волю и единое действие: поэтому познание Одного из Лиц - невозможно. «Бог Отец, Бог Сын, Бог Дух Святой: не три бога, но один Бог; не одно лицо, но три» - одна из святоотеческих формулировок тринитарного догмата, отразившая мистический опыт древней Церкви; «Бог един по существу и троичен в Лицах», «Троица единосущна и нераздельна», «Троица - Единица» - еще более краткие формулировки.

По меньшей мере, наивно думать, что истины такого рода легко постижимы. Мы знаем, с каким трудом поддается познанию даже материальный мир вокруг нас; неужели познание Бога, сотворившего весь этот мир и нас самих, должен быть делом более легким!

В силу этих причин знание способов познания догмата о Пресвятой Троице является очень важным этапом приближения к Богу верующих людей и воцерквления людей колеблющихся. Согласно Православному Догматическому богословию догмат Святой Троицы включает в себя две основные истины:

1) Бог есть един по Существу, но Троичен в Ипостасях, или другими словами: Бог - Триединый, Триипостасный, Троица Единосущна.

2) Ипостаси имеют личные (ипостасные) свойства: Отец не рожден; Сын рожден от Отца; Дух Святой исходит от Отца.

Верующие поклоняются Святой Троице единым нераздельным поклонением. В большинстве случаев молитвы, обращенные к поклоняемому одному Лицу Святой Троицы, заканчиваются славословием всем трем Лицам. Так в молитве Господу Иисусу Христу: «Яко препрославен еси со Безначальным Твоим Отцем и Пресвятым Духом во веки, аминь». Догмат триипостасности указывает на полноту таинственной внутренней жизни в Боге, ибо Бог естъ любовъ (1 Ин. 4, 8; 4, 16), и любовь Божия не может простираться только на сотворенный мир: она в Святой Троице обращена и внутрь Божественной жизни.

В нас и во всем творении - Своей силою и благодатью - Дух Святой, Иже вся исполняй, жизни Податель, Животворящий, Утешитель, Сокровище и Источник благ. Три Божественных Лица, имеющие превечное и предвечное бытие, явленъ миру с пришествием и воплощением Сына Божия, будучи «едина Сила, едино Существо, едино Божество» (стихира в день Пятидесятницы).

Догматическое богословие утверждает, что Сущность Божия недоступна для человеческого разума, и мы можем говорить лишь о свойствах существа Божия или о существенных свойствах Божиих. Среди множества Божественных свойств выделяют две большие группы: апофатические (отрицательные), которые показывают, что Бог обладает всей полнотой бытия, абсолютной сущностью и катафатические (положительные), которые показывают, что Бог есть духовноразумное существо, или Личность. К апофатическим относят такие свойства как: Самобытность, Неизменяемость, Вечность, Вездеприсутствие и Неизмеримость. К катафатическим - такие, как: Разум, Премудрость, Святость, Свет, Всемогущество, Всеблаженство, Благость, Любовь, Милость, Правда.

Святые Отцы - святитель Григорий Богослов, преподобный Иоанн Дамаскин и другие писали о том, что Божественная природа по своей сущности проста и несложна. Наша множественность представлений о Боге (Его имен) связана с ограниченностью нашего послегреховного восприятия. Бог как таковой Неизречен и Невыразим, и Сущность Его безымянна. Свойства существа Божия в Нем Самом сливаются, но когда мы говорим о человеке или любом предмете природы, то разделяем их свойства для того, чтобы потом обобщить. В Боге нет разделения между самой природой и свойствами, поэтому Он обладает всеми свойствами, и они сливаются воедино.

Познание догмата (истины) Святой Троицы (Бога) возможно двумя принципиально различными путями: путем Божественных Откровений, даваемых человеку (людям), и путем познания Бога посредством человеческой мысли или обращения к своей душе. Рассмотрим эти пути познания Бога подробней.

Вначале отметим, Божественные Откровения, даваемые людям, предстают как свидетельства Священного Писания Ветхого Завета и как свидетельства Священного Писания Нового Завета. Причем, в первых свидетельствах истина триединства Божия лишь прикровенно выражена в Ветхом Завете, она только приоткрыта; во вторых, то есть новозаветных Писаниях, приводятся изречения о Триедином Боге, в самой сжатой, но притом точной форме выражающие истину троичности. 


\section{Философия религии}

Главные ветхозаветные места Откровений следующие:

Быт. 1, 1 и др.: имя «Элогим» в еврейском тексте, имеющее грамматическую форму множественного числа.

Быт. 1, 26: И сказал Бог: сотворим человека по образу Нашему и по подобию Нашему. Множественное число указывает, что Бог - не одно Лицо.

Быт. 3, 22: И сказал Господь Бог: вот, Адам стал как один из Нас, зная добро и зло (слова Божии перед изгнанием прародителей из рая).

Быт. 11, 6-7: перед смешением языков при Вавилонском столпотворении - Один народи один у всех язык... Сойдем же и смешаем там язык их.

Быт. 18, 1-3: об Аврааме - И явился ему Господь у дубравы Мавре..., возвел (Авраам) очи свои, взглянул, и вот, три мужа стоят против него... и поклонился до земли, и сказал: Владыка! если я обрел благоволение перед очами Твоими, не пройди мимо раба Твоего. Как наставляет блаженный Августин Аврелий: «Видите ли, Авраам встретил Трех, а поклоняется Единому... Узрев Трех, он уразумел таинство Троицы, а поклонившись как Единому - исповедал Единого Бога в трех Лицах».

Наконец, можно отметить в Ветхозаветном Откровении места, где говорится порознь о Сыне Божием и Духе Святом.

\section{О Сыне:}

Пс. 2, 7: Ты Сын Мой; Я ныне родил Тебя.

Пс. 109, 3: ...из чрева прежде денницы подобно росе рождение Твое.

\section{О Духе:}

Пс. 142, 10: Дух Твой благий да ведет меня в землю правды.

Ис. 48, 16: ...послал Меня Господь и Дух Его.

В Ветхозаветном Откровении имеются и другие подобные места.

Троичность Лиц в Боге явлена в Новом Завете в пришествии Сына Божия и в ниспослании Духа Святого. Послание на землю от Отца Бога Слова и Духа Святого составляет содержание всех новозаветных писаний. Конечно, явление миру Триединого Бога дано здесь не в догматической формуле, а в повествовании о явлениях и деяниях Лиц Святой Троицы.

Явление Бога в Троице совершилось при крещении Господа Иисуса Христа, отчего и само крещение называется Богоявлением. Сын Божий, вочеловечившись, принял водное крещение от Иоанна Крестителя; Отец свидетельствовал о Нем;
Святой Дух явлением Своим в виде голубя подтвердил истинность гласа Божия, - как это выражено в тропаре праздника Крещения Господня: «Во Иордане крещающуся Тебе, Господи, Троическое явися поклонение, Родителев бо глас свидетельствовавше Тебе, возлюбленного Тя Сына именуя, и Дух, в виде голубине, извествовавше словесе утверждение».

В новозаветных Писаниях есть изречения о Триедином Боге в самой сжатой, но при том точной форме выражающие истину троичности. Эти изречения следующие:

Мф. 28, 19: Итак, идите, научите все народы, крестя их во имя Отца и Сына и Святаго Духа. - Св. Амвросий замечает: «Сказал Господь: во имя, а не во имена, потому что один Бог; не во многие имена, потому что не два Бога и не три Бога».

2 Кор. 13, 13: Благодать Господа (нашего) Иисуса Христа, и любовь Бога (Отща), и общение Святого Духа со всеми вами. Аминь. Из этого высказывания следует, что ипостаси Триединого Бога проявляют себя в различных функциях (свойствах), взаимодополняющих друг друга.

1 Ин. 5, 7: Ибо три свидетельствуют на небе: Отец, Слово и Святой Дух; и эти три есть суть едино. (Этот стих имеется только в латинских, западных рукописях, и отсутствует в сохранившихся древних греческих рукописях).

Кроме того, в значении Троичности изъясняет св. Афанасий Великий следующий текст послания к Еф. 4, 6: Один Бог и Отец всех, Который над всеми (Бог Отец) и через всех (Бог Сын) и во всех нас (Бог Дух Святой).

Святые отцы (в том числе Поликарп Смиренский, Ириней Лионский, Василий Великий, Иустин Мученик, Григорий Богослов и другие), защищая от еретиков кафолическую истину Святой Троицы, не только приводили в доказательство свидетельства Священного Писания, а равно и основания рассудочные, философские для опровержения еретических мудрований, - но и сами опирались на свидетельства первых христиан. Имеется много свидетельств древних отцов и учителей Церкви также о том, что Церковь от первых дней своего бытия совершала крещение во имя Отца и Сына и Святого Духа, как трех Божеских Лиц, и обличала еретиков, покушавшихся совершать крещение или во имя одного Отца, считая Сына и Святого Духа низшими силами, или во имя Отца и Сына и даже одного Сына, унижая перед ними Святого Духа (свидетельства Иустина Мученика, Тертуллиана, 


\section{Философия и культура 4(64) • 2013}

Иринея, Киприана, Афанасия, Илария, Василия Великого и других).

Однако Церковь пережила большие волнения и выдержала упорную борьбу при защите этого догмата. Борьба была направлена, главным образом, по двум пунктам: сначала на утверждение истины единосущия и равночестности Сына Божия с Богом Отцом; потом - на утверждение единочестности Духа Святого с Богом Отцом и Сыном Божиим. Именно в этой борьбе познания Божественных Откровений, Церковь уже с четвертого века выработала форму понятия этих откровений: эту работу совершает свободный соборный догматический разум (Вселенские Соборы). Конечно, сочетание: «свободный» и «догматический» в наше время звучит парадоксом, но это еще одна из истин, составляющих сущность христианства, и также не из самых легких для постижения.

Свободный соборный догматический разум Вселенских Соборов имеет под собой и методологическую основу. Известно, что Божественные Откровения носят частный характер и даются различным людям, устремленным к Богу. В изложении игумена Троице-Сергиевой Лавры Исаии это представлено следующим изречением: «Каждый святой получает свою, частную меру откровения единой полной Божественной Истины» ${ }^{1}$. Поэтому постановления Вселенских Соборов (которые не подлежат последующему пересмотру и изменению) догматически и методологически обобщают частные откровения, тем самым постепенно приближая их к единой полной Божественной Истине.

Этому же приближению служит путь познания Бога посредством человеческой мысли или обращения к своей душе. Когда мысль человек направляется к уразумению жизни Бога в Самом Себе, эта мысль теряется в своей беспомощности и приходит лишь к сознанию неизмеримого и непостижимого величия Божия, непроходимой разницы между тварью и Богом, такой разницы, что невозможно делать никакого сравнения между ними. Тем не менее, этот путь познания Бога в Триединстве Его Ипостасей не должен слишком умаляться и отрицаться, так как он дает возможность, постигая величие Божия, совершенствовать свой тварный разум, постепенно познавая (раскрывая для себя) идеально совершенные свойства и сущ-

\footnotetext{
${ }^{1}$ Россия перед Вторым пришествием (Материалы к очерку Русской эсхаталогии). Издание второе. М., 1994. С. 5; Августин Аврелий. О Троице: в пятнадцати книгах против ариан. Научное издание. Краснодар: Глагол, 2004. 416 с.
}

ности Пресвятой Троицы и Ее Лиц (Ипостасей) и подражая (приближаясь) им. Таким путем шли многие святые отцы и старцы, постигая крупицы Истины, и совершенствуясь сами. В качестве примера можно привести Августина Аврелия (Блаженного), написавшего трактат «О Троице» (Пятнадцать книг о Троице против ариан) ${ }^{2}$. Другими словами, этот, хотя и трудный путь сопряжен с двоякой пользой: познания (приближения к Богу) и совершенствования собственной тварной личности перед Идеальной Личностью Бога.

Когда та же мысль верующего человека обращается к познанию Бога в мире, в действиях Божиих в мире, она всюду, во всем, видит силу Божию, мысль Божию, благость и милость Божию. Ибо невидимое Его, вечная сила Его и Божество, от создания мира через рассматривание творений видимы, так что они безответны (Рим. 1, 20).

Далее, обращаясъ $\boldsymbol{\kappa}$ своей душе, углубляясь в себя самого, сосредотачиваясь в молитве, пребывая в Церкви Христовой, человек по мере своего духовного роста становится способным уразумевать невыразимую словами близость Божию к Его творению, в особенности же к человеку. Перед духовными глазами верующего православного человека предстает бездна - безграничная и светлая - все превосходящей любви Божией к каждому из нас, открывающейся в ниспослании в мир и в крестной смерти Сына Божия ради нашего спасения.

Значение чудес, совершенных Спасителем, как дело служения любви безмерно и в тоже время в них раскрываются глубокие педагогические аспекты, как осуществление творения новой материи: чудо умножения хлебов (Мф. 15, 32-38; Ин. 6, 1-15), чудо претворения воды в вино (Ин. 2, 1-11); преодоление нерушимых законов природы Силой, большей, чем эти законы: чудо хождения по воде (Ин. 6, 15-19; МФ. 14, 25), воскрешение сына Наинской вдовы (Лк. 7, 11-15), воскрешение Лазаря (Ин. 11, 43-44), явление Воскресшего Господа Марии Магдалине и другой Марии (Ин. 20, 11-18; Мф. 28, 9-10), явление Воскресшего Господа десяти ученикам (Ин. 20, 19-23), явление Иисуса Христа одиннадцати ученикам на восьмой день по Воскрешении (Ин. 20, 24-31), явление Господа ученикам при море Тивериадском (Ин. 21, 1-24) и на горе в Галилее (Мф. 28, 16-20; Лк. 24, 46-49) и, наконец, Вознесение Господне (Лк. 24, 49-53; Мк. 16, 19-20).

И самым величайшем чудом для нас будет Второе прииествие Христово. 


\section{Философия религии}

Чудо необходимо воспринимать не как феномен, а как сущность. «Чудо - фундаментальная реальность мира, смысл мира, открытость его бытия. Чудо проходит через все мировые уровни, вернее, образует их и, достигая человека, преображается в чудо спасения ${ }^{2}$.

Апофатический путь богопознания в богословии указывает нам, что через отрицание мы можем приблизиться к пониманию Бога в той мере, в какой это возможно для нас. Бог находится в недоступном Божественном мраке, поэтому святитель Григорий Богослов и говорит о Сущности Божией: «Изречь невозможно, а уразуметь еще более невозможно» ${ }^{3}$.

Непознаваемость Бога в Сущности не означает отказа от богопознания, ибо нам дана возможность по благодати соединиться с неизреченной Божественной Благодатью, с Бесконечностъю Бесконечностей Божественных энергий. При этом мы должны отказаться от восприятия Бога как Субъекта или Объекта нашего восприятия в смысле противопоставления Бога и человека, так как в нашем обожении речь идет не о познании, а о соединении, о всеединстве внешнего и внутреннего в человеке с полнотой благодати в Царстве Небесном ${ }^{4}$.

B XIV в. известный богослов, святитель Григорий Палама в споре с ученым-монахом Варлаамом Калабрийцем о познаваемости Бога разработал учение о непостижимости Бога в Своей Сущности и познания Его в действиях, или энергиях. Основные положения этого учения следующие.

1. Между Сущностью и сущностной энергией Бога является «богодостойное различие». Они «различаются без расхождения». Сущность - причина энергии. Сущность не допускает причастности к Себе, а энергия допускает причастность к Себе. О Сущности можно говорить только в единственном числе, а об энергии и в единственном, и во множественном числе. Сущность безымянна, а энергия - именуется.

2. Энергия есть «нетварная и природная благодать и озарение, неисходно выходящие» от Божьей Сущности.

\footnotetext{
2 Сошинский С.А. Чудо в системе мироздания // Вопросы философии. 2001. № 9. С. 97.

3 Григорий Богослов свт. Слово 45 на Св. Пасху. Творения. Т. 1. Свято-Троицкая Сергиева Лавра, 1994. С. 661-663.

4 Лосский В.Н. Очерки мистического богословия восточной церкви. М., 1991. С. 244-245.
}

3. Различая в Боге Сущность и природную энергию, мы не вводим двубожья и не нарушаем Божьей простоты.

4. К энергиям можно прилагать имя «Божества», так как энергия неотделима от Сущности Бога. Божественные энергии - Сам Бог вне Его Сущности (особый образ бытия Бога вне Его Сущности).

5. Можно говорить, согласно с Преданием, что Сущность выше энергии, потому что энергия исходит из Сущности, а не наоборот.

6. Причастность Богу есть причастность Его энергии. Можно приобщаться не к Божественной Сущности, но к Божественным энергиям.

7. Свет Преображения не сотворен, но есть вечное сияние Божества.

Подробно разработав учение о Божественных нетварных энергиях и всецело основываясь на Священном Писании и творениях Святых Отцов Церкви, святитель Григорий Палама излагает его в работе «Триады в защиту священнобезмолствующих». Важно подчеркнуть, что энергии не суть ипостаси, ибо нет в Боге иных ипостасей, кроме Лиц Пресвятой Троицы. Он пишет о том, что «Ни одна из энергий не ипостасна, то есть не само - ипостасна, энергия эта присуща всем трем Лицам Пресвятой Троицы, она одна числом, но многообразна в своих проявлениях, выступлениях,

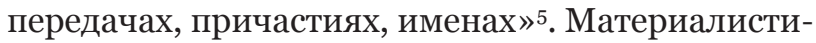
ческой науке потребовалось порядка 500 лет для того, чтобы после св. Григория Паламы уразуметь эту связь между единством Божественной энергии и многообразием Ее проявлений в сотворенном мире. Лишь в первой четверти XX в. А.А. Богданов, исследуя общие принципы организации в различных сферах, обратил внимание на «скудность» организации форм Природы (материи) при фантастическом разнообразии проявления этих форм в явлениях и процессах материального мира $^{6}$. Констатация этого феномена природы не может быть логически завершена без ответа на вопрос: почему это так, а не иначе?

В соответствии со Священным Писанием: И увидел Бог все, что Он создал, и вот хорошо весьма (Быт. 1, 31) объяснение можно дать следующее. Природа (сотворенный мир), в отличие от бравого рассудка, избегает уходить в дурную бесконеч-

\footnotetext{
${ }^{5}$ Керн Киприан арх. Антропология св. Григория Паламы. М.: Паломник, 1996. С. 290

6 Богданов А.А. Всеобщая организационная наука. Тектология. СПб: Издание Семенова, 1912-1929. 4.1-3.
} 


\section{Философия и культура 4(64) • 2013}

ность. Формальное продолжение обычно срывается в коллапс. Коридор многообразного проявления Божественных энергий достаточно узок.

Сам Господь заповедовал нам: Bходиme mecными вратами, потому что широкие врата и пространен путь, ведущие в погибель (Мф. 7, 13). Сотворенный мир соответствует трехмерному пространству. В физике в 1917 году П. Эренфест установил, что трехмерность обладает определенными преимуществами, так как при меньшей размерности не могут возникать сложные структуры, а при большей - не могут существовать устойчивые атомы и планетарные системы ${ }^{7}$ Автору этой работы пришло озарение, что организация форм природы (материи) соответствует свойствам Святой Троицы: она троична, триедина и триалестична ${ }^{8}$. И этому имеется множество доказательств природных феноменов, явлений и процессов, которые можно обобщить в Истину: Святая Троица является Прообразом всего сущего. Все другие обобщения ведут к ереси.

Мнимых путей восхождения к Богу известно много в разных религиях, но все они отличны от Истины и порождают ересь. Первая антитринитарная ересь - арианская, была направлена именно на то, чтобы разрушить веру в сущностное тождество Отца и Сына. В борьбе с арианством (в качестве примера можно привести Августина Блаженного, написавшего трактат «О Троице») и последующими ересями выковалось учение о Святой Троице: термин «единосущие» был введен (на 1 Вселенском Соборе в Никее, 325 г.) в недра невидимой Троицы и стал означать природное сущностное тождество Трех Лиц.

Сопоставляя тринитарный догмат с учением св. Григория Панамы об Энергиях, можно утверждать, что термин «единосущие» истинен в двух неразрывных смыслах: Три Лица единосущны друг другу и Троица единосущна Своей Энергии. Последний смысл приоткрывает возможность познания догмата Пресвятой Троицы через проявления в мире Божественных Энергий (благодатей и озарений).

Апофатический путь богопознания является «духовной лестницей», ведущей нас к осознанию непознаваемости сущности Бога. Познавая Бога

\footnotetext{
7 Баранцев Р. Г. Становление тринитарного мышления. М.Ижевск: НИЦ «Регулярная и хаотическая динамика», 2005. 124 c. C. 54

${ }^{8}$ Корень Р.В. Теория триединых систем как методологическая основа и функциональный инструментарий фундаментальных исследований. Краснодар: Изд-во НКА, 2007. 80 с. С. 4-6.
}

через положительные свойства Божественных энергий и двигаясь вверх по «духовной лестнице», мы отрешаемся от всего бытийного и нарекаем Ему отрицательные имена: Самобытность, Неизменяемость, Вечность, Неизмеримость и Вездеприсутствие, Неизреченность и вот мы уже доходим до той предельной вершины, «где совершенные, неизменяемые и подлинные таинства богословия открываются в Пресветлом мраке тайноводственного безмолвия» 9 . Быть в Божественном мраке значит посредством невидения и неведения видеть и разуметь Сущего выше всякого знания в самом неведении и невидении, и это неведение есть свет и знание, превосходящее все познание.

Рассматривая вопрос о Божественных энергиях и Божественном знании, нельзя не сказать о том, что понятие «свет» было для западных ученых и теологов средневековья и нового времени силой самой природы, ее онтологической формой. Свет есть принцип существования и принцип познания, единство материи и формы к такому выводу приходили средне-вековые физики и метафизики.

Онтологическая форма понятия «свет» в большей степени проявляется при рассмотрении Божественных энергий и Божественного знания при их рассмотрении в связи с единством сотворенного мира. Свет является одним из имен Сына Божиего: Опять говорил Иисус к народу и сказал им: Я свет миру; кто последует за Мною, тот не будет ходить во тьме, но будет иметь свет жизни (Ин. 8,12$)$ и одной из основных форм проявления Божественных энергий в сотворенном мире.

К. Леонтьев, изучая свойства солнечного света, установил фундаментальные законно-мерности общности различных свойств семи различных явлений, которые свидетельствуют о существовании более общих принципов единства и порядка, сущность которых трудно или невозможно объяснить в рамках специальных областей естествознания, так как они относятся не только к традиционным областям науки, но и к метафизики и даже богословию. Рассматривая порядок чисел, принадлежащих к приведенной в первой Книге Библии, родословной Адама и последующих патриархов, автор установил, что по приведенным в родословной числам можно определить даты рождения и смерти каждого из глав поколений. В этом отношении

\footnotetext{
9 Ареопагит Дионисий свт. Мистическое богословие. М.: Тетра, 1993. С. 3, 7-8.
} 


\section{Философия религии}

известный тысячелетиями текст Библии не менее объективен, чем использованные выше научные данные, следующие одной закономерности ${ }^{10}$. Рассмотренные К. Леонтьевым примеры очевидны, обнаруживают признаки системной взаимосвязи и подтверждают слова ряда ученых и мыслителей о том, что единство Святой Троццы является обцей основой всего суццего.

Говоря о богопознании, нельзя не сказать несколько слов о тайне Пресвятой Троицы. Святые Отцы учили, что в Троице нет места счисления, так как в Божественном бытии нет дискретной множественности, которую можно сосчитать, то есть количество три из количественной категории преображается в качественную. Иоанн Дамаскин говорит о Троице Единосущной и Нераздельной: «Божество - простое и несложное»; а святитель Григорий Богослов писал о Троице как о «Трех бесконечных бесконечная соотнесенность» ${ }^{11}$. Это определение по сути своей сродни понятию Бесконечность - Бесконечностей, как Вечность и Неизмеримость, однако воспринятое ранее автором, как имманентное материальному миру, как бесконечность мироздания и неисчерпаемость форм разума.

Сущность Божия находится вне человеческого способа познания, основанного на парных противоположных категориях (конечное-бесконечное, материя-сознание, форма-содержание, качествоколичество и т.д.). Ее невозможно описать и в синтезе единства, то есть Она за пределами множественного и Единого... в безмолвии и безмыслии. Явление Спасителя Иисуса Христа в мир упраздняет собою «дурную бесконечность» мира сего ${ }^{12}$ и открывает нам по переизбытку благости «Бога в себе» во всей полноте «Бога все во всем» (1 Кор. 15, 28). Последнее выражение познания «Бога все во всем» открывает еще один способ познания догмата Святой Троицы в сотворенном мире. На это указывает и Священное Писание. Бог создал мир совершенным. После того как созданы были все земные твари, и сказал Бог: сотворим человека по образу Нашему и по подобию Нашему... И сотворил Бог человека, по образу Божию сотворил его... (Быт. 1, 26-27). В завершении шестого дня

\footnotetext{
10 Леонтьев К. Энергия и единство мира // Природа и человек («Свет»). 1997. № 1. С. 16-18.

11 Григорий Богослов свт. Творения. Т. 3. М., 1911. С. 417.

12 Корень Р.В. Экология медиапространства: Бравый рассудок, «медиаиблисы» и живая клетка. Краснодар: Изд-во HKA, 2011. $36 \mathrm{c}$.
}

творения: И увидел Бог все, что Он создал, и вот, хорошо весьма (Быт. 1, 31).

Имеются различные толкования совершенства сотворенного мира и «образа и подобия», но в данном случае определяющим является образ Святой Троицы. В чем же заключается совершенство сотворенного мира? И что означает творение человека «по образу Божию»? На оба эти вопроса может быть дан только один ответ: все творения Бога имеют троичную природу (структуру). В случае человека это: дух, душа и тело. В случае всех остальных свойств сотворенного мира и явлений природы имеет место также проявление троччности (триединых систем). В таком подходе можно опереться и на работы Святых Отцов Церкви (в частности, работу Григория Паламы «Триады в защиту священнобезмолствующих») и работы ученых. В общем виде проблема богопознания, в свете полемики между Варлаамом и Паламой, а также культурологических разработок автора этой статьи, более подробно рассматриваются ${ }^{13}$ в параграфе 2.11. «Взаимодополнение богословия и системной культурологии (Метанауки)» ${ }^{14}$.

Корректное познание Догмата Пресвятой Троицы, диалектически требует проверки «внешней среды» на соответствие её Прообразу (матрице) или, другими словами, требует рассмотрения следствий познания Основополагающего Догмата.

В этой связи нам представляется уместным отметить, что вновь испеченные поводыри (священники), сводящие свой арсенал поиска истины догмата Святой Троицы лишь к свидетельствам Священного Писания, неучитывают веяния времени (хотя широко используют в быту технические достижения науки и техники) и, тем самым, проявляют леность ума и демонстрируют недостаточность знаний Догматического богословия, основ философии, культурологии и современного естествознания. Другими словами, такие поводыри, уделяя основное внимание окормлению, требам, службам и собственному кормлению, не следуют заповедям Иисуса Христа: «Будьте совершенны, как Отец ваш Небесный».

А между тем для пытливого ума есть место в познании других, соподчиненных Святой Троице догматов, и их провозглашенных оснований.

\footnotetext{
13 Корень Р.В. Быть честным перед Богом. Очерки философско-богословских озарений и размышлений. Краснодар: Издательство НКА, 2012. 256 с.

${ }_{14}$ Корень Р.В. Этюды для системной культурологии (Метанауки). Краснодар: Изд-во НКА, 2008. 96 с.
} 


\section{Философия и культура 4(64) • 2013}

Православное Догматическое богословие признает два источника оснований догмата: Священное Писание и Апостольское Священное Предание и считает, что они дают полноту учения веры, именуемую древними отцами Церкви «Соборной верой», «кафолическим учением» Церкви. С другой стороны, в Православном Догматическом богословии догмат Пресвятой Троциы (или догмат Троичности) имеет Высшую иерархию, так как на нем непосредственно основывается ряд других великих догматов Церкви, и, прежде всего, догмат нашего искупления (учение о спасении). Учение о Пресвятой Троице составляет содержание всех символов веры, какие употреблялись и употребляются в Православной Церкви, а также и всех частных исповеданий веры, написанных по разным случаям пастырями Церкви.

Все это дает основание поставить вопрос о недостаточности двух источников оснований догмата, так как это противоречит триединой сущности основополагающего догмата Святой Троицы (Триединства Бога). Поэтому и источников оснований догмата должно быть $\mathbf{m p u}$. Сама постановка такого вопроса ни в коей мере не затрагивает существа богословских догматов, но определяет методологию подхода к определению источников оснований догмата. За этим вопросом следует второй: какого же источника не достает? Ответ на последний вопрос поищем в самом догмате Святой Троицы (Троичности Бога) и комментариях (свидетельствах) к нему.

Троичность Лиц в Боге явлена в Новом Завете в пришествии Сына Божия и в ниспослании Духа Святого. Послание на землю от Отца Бога Слова и Духа Святого составляет содержание всех новозаветных писаний. Конечно, явление миру Триединого Бога дано здесь не в догматической формуле, а в повествовании о явлениях и деяниях Лиц Святой Троицы. Особая форма богооткровения в слове есть богооткровение в именах Божиих ${ }^{15}$.

Божественная сторона имени Божия есть как бы «самоопределение» Божие или мысль Бога о Себе Самом. Имя Божие Свято, и Бог Сам святит Себя в Своем имени (Лев. 22, 32). Бог действует ради Своего имени (Иез. 39, 7, 25). Бог действует через него (Пс. 54, 3). Наконец, замечательно, что Бог открывает Свои имена (Исх. 3, 13-14; 6, 3; 33, 19; Иер. 23, 6).

\footnotetext{
15 Протопресвитер Михаил Помазанский. Православное Догматическое богословие. М.: Издательский Совет РПЦ, 2005. С. 77.
}

Бог близок человеку в Своих именах $($ Пс. 75, 2). Богоприсутствие равносильно присутствию имени Божия. Имя Божие пребывает по всей земле. Имена Божии, о которых пойдет речь ниже, особенно четко представлены в Святом Благовествовании от Иоанна: Вначале было Слово, и Слово было у Бога, и Слово было Бог. Оно было вначале у Бога. Все через него начало быть, и без него ничего не начало быть, что начало быть. В нем была жизнь, и жизнь была свет человеков. И свет во тьме светит, и тьма не объяла его (Ин. 1, 1-5).

И далее: Был человек, посланный от Бога, имя ему Иоанн. Он пришел для свидетельства, чтобы свидетельствовать о Свете, дабы все уверовали в него. Он не был свет, но был послан, чтобы свидетельствовать о Свете. Был Свет истинный, Который просвещает всякого человека, приходящего в мир. И мир был, и мир через Него начал быть, и мир Его не познал. Пришел к своим, и свои Его не приняли (Ин. 1, 6-11).

Опять говорил Иисус к народу и сказал им: Я свет миру; кто последует за Мною, тот не будет ходить во тьме, но будет иметь свет жизни (Ин. 8, 12).

Бог есть Истина, Знание, Премудрость. Быть истиной - значит быть светом, т. е. всецело явленной действительностью. В таком случае источники оснований догмата: Священное Писание и Апостольское Священное Предание являются отражением действительности или отраженнымм светом.

Часто встречающееся у святых отцов и в богослужебных текстах именование Сына Божия Словом, или Логосом, имеет свое основание в первой главе Евангелия Иоанна Богослова (см. выше). Понятие, или имя Слова в его возвышенном значении, неоднократно находим и в ветхозаветных книгах. Таковы выражения в Псалтире: $\mathrm{Ha}$ веки, Господи, слово Твое утверждено на небесах (Пс. 118, 89); Словом Господа сотворены небеса, и духом уст Его - все воинство их (Пс. 32, 6). Автор Премудрости Соломоновой пишет: Сошло с небес от циарственных престолов на середину погибельной земли всемогущее Слово Твое, как грозный воин. Оно несло острый меч - неизменное Твое повеление, $и$, ставии, наполниловсе смертью, оно касалось неба и ходило по земле (Прем. 28, 15-16).

После схождения на землю Господа Иисуса Христа с Благой Вестью меняется тональность (направленность) Слова. Слова Ветхого Завета: Люби ближнего своего, но ненавидь врага своего 


\section{Философия религии}

(Лев. 19, 18). Слова Нового Завета: $Я$ же говорю вам: Любите врагов своих и молитесь за тех, кто преследует вас, и тем самым будете детьми Отца Небесного... Итак, будьте совершенны, как совершенен Отец ваш Небесный (Матф. 5, 44-45, 48). Ветхий Завет, признавая, что Бог есть Господь всей вселенной, связывал Бога преимущественно с Израилем как богоизбранным народом. Новый Завет видит в Сыне Божием Примирителя и Соединителя всех народов между собой и с Богом. Христос напоминает людям заповедь Второзакония: Господь Бог наш есть Господь единый (Мк. 12, 29).

Итак, прямое Слово есть именование Второго Лица Триединого Бога ${ }^{16}$, а Священное Писание и Апостольское Священное Предание являются изложением Слова, не всегда учитывающим изменение Его тональности. Это еще один аргумент в защиту необходимости $\boldsymbol{m p e -}$ mъего источника оснований догмата. Правда, «Отождествление имени Божия как слова с Самим Богом есть ересь, осужденная в XX веке русским Св. Синодом» ${ }^{17}$. Указанное постановление русского Св. Синода лишний раз подчеркивает недостаточность двух источников оснований догмата и в неявной форме свидетельствует о необходимости обеспечения их достаточности. ${ }^{16}$

Возможным истоком этой недостаточности является следующее обстоятельство. Когда Христос тосковал и скорбел в Гефсиманском саду, ученики Его спали, несмотря на просьбу Христа бодрствовать с Ним. Сильнейшая скорбь Сына Божия перед лицом Своей смерти и зла всего мира (ибо из-за нас Ему надлежало умереть) не вызвала сострадания учеников, хотя и за них должен был умереть Христос. Они спали «по немощи плоти»... Христос же бодрствовал и смертельно скорбел за всех. Как можно понимать «по немощи плоти»? Нам трудно рассчитывать на то, что Евангелие представит нам Спасителя как живого собеседника и передаст нам Его силу как мыслителя. Сам Христос книг не писал, а передавал свое учение малограмотнъым людям, которые понимали Его как могли. По интеллектуальному уровню перед Ним были дети, поэтому, чтобы хоть что-то у них отложилось, Ему приходи-лось все разжевывать, использовать многочисленные повторы, а какие-то места аргументировать не логикой, а угрозами. О каких-то

\footnotetext{
16 Верховский С.С. Бог и человек: Учение о Боге и богопознании в свете православия. М.: Православный Свято-Тихоновский гуманитарный университет, 2004. С. 62.
}

вещах там вообще говорить бессмысленно, ибо рядовое невежество одномоментно не преодолевается даже Духом Святым. Кроме того, лишь двое из евангелистов были апостолами: Матфей и Иоанн. Лука входил в число 70 учеников Иисуса Христа. Он был одним из первых образованных язычников, принявших благовестие Христа. Евангелист же Марк примкнул к общине христиан и принял активное участие в миссионерской деятельности апостола Павла, а позже сделался постоянным спутником и участником апостольских трудов апостола Петра.

$\mathrm{A}$, как известно, при передаче информации она подвергается искажениям ${ }^{18}$.

В Православном Догматическом богословии, считающим достаточным лишь двух источников оснований догмата, по тем или иным причинам, делает присутствие Бога не очевидным (в смысле отсутствия в источниках оснований догмата прямого Слова Бога). Ссылка на «Гармонически сливающиеся в одно целое истины Писания и Предания определяют собой «Соборное сознание» Церкви, руководимое Духом Святъмм», в данном случае обезличено, поскольку именно Святой Дух непосредственно явлением Своим в виде голубя подтвердил истинность гласа (Слова) Божия. А именно «алас Божий» отсутствует в источниках оснований догмата. Закон дан через Моисея, благодать же и Истина произошли через Иисуса Христа.

Много раз Новый Завет упоминает о необходимости бодрствования в ожидании неожи-данного наступления конца мира и Страшного суда (напр., Мф. 24, 42). Значение конца мира всеобъемлюще, но средоточие его - в явлении Господа. В этом мире присутствие Бога не очевидно для большинства людей. Бодрствование есть постоянная память о Боге, сознание нашей нерушимой непосредственной связи со Христом (а не отзвуки пересказа об этой связи) и приготовление нашей души как храма для Бога или как невесты для Жениха. Любовь к Богу и Христу должна превосходить всякую иную любовь. Тот, кто любит Христа меньше своих родных (и исключает из источников оснований догмата - P.К.), недостоин Его (Мф. 10, 37). Любовь к Богу по мере своего возрастания дает нам и многостороннее знание Бога; так как любовь есть единение, следовательно, в любви мы соединяемся с Богом и познаем Его всего, сколько это возможно для нас.

И эта любовь, единение и познание Бога нашего Иисуса Христа требуют, чтобы первъм 
источником оснований догмата было Учение Иисуса Христа и прямое Слово Господне от времен Его земной жсизн, в первую очередь, «Нагорная проповедь» и Пятое Евангелие от Фомы. Два других источника оснований догмата долюнны его дополнять, разъяснять, утверждать. И это будет соответствовать основополагающему догмату Пресвятой Tроццъ (Триединства Бога и Его проявлений в миру: триединству всего сущего). И в этом заключается Премудрость. Она, как все в мире, имеет один источник - в Боге. Господь дает мудрость, из уст Его - знание и разум (Притч. 2, 6). Бог есть руководитель к мудрости и исправитель мудрых (Прем. 7, 15) ${ }^{17}$.

Чтобы утвердиться в этой Истине, кратко рассмотрим основные положения Учения Иисуса Христа. Доминантой оригинальности Учения является: Будъте прохожими ${ }^{18}$. Во-первых, эти слова констатируют непрерывность существования. А во-вторых, пришедший на Землю должен ее покинуть, но что он может взять с собой? Явно ничего из материальных накоплений, а вот духовное богатство ему не помешает.

Нагорная проповедъ являет собой истинную суть Учения Иисуса Христа, его методологическую основу, органично вмещающую в себя как нормы поведения искреннего искателя Истины в мирской жизни, так и практики достижения полного единения с Господом. Надо отметить, что в Нагорной проповеди нет той убийственной бытовой конкретики с массой всевозможных запретов и разрешений, которая присуща заповедям Ветхого Завета, что вуалирует суть Единобожия. Восприятие проповеди требует предельного сердечного внимания, а это возможно только при искреннем сердечном стремлении к Господу. Иисус прямо говорит об этом: Ктmо имеет уuи, да усльиитт.

Из Ветхого Завета Иисусом Христом был взят, по сути, лишь принцип Единобожия. В остальном же - Он подлинный революционер. Чтобы не вызывать ненужный гнев ревнителей Ветхого Завета Он говорит, что пришел не нарушать, оставленное пророкали, но исполнять (или восполнять - P.K.). Но на деле Он полностью

\footnotetext{
17 Краснов А.М. Искажение информации в процессе познания // Рационализм и культура на пороге третьего тысячелетия: Материалы III Российского Философского конгресса. Ростов-н/Д, 2002. Т. 1. С. 54-55.

18 Таранов П.С. Мудрость трех тысячелетий. М.: АСТ, 1997. 736 c. C. 198.
}

обновляет оставленное пророками, а это в корне меняет суть Его откровений.

Иисус не предлагает пересматривать Ветхий Завет, не предлагает никаких компиляций - Он предлагает принципиально новое Учение, да и Сам Он - Учитель новой формации, каких не было до Него. Ключевая фраза всего Учения Иисуса Христа, произнесена Им в Нагорной проповеди: Итак, будыте совериенны, как совериенен Отец ваши Небесный.

Апокрифическое Евангелие от Фомы ${ }^{\underline{19}}$, в котором собраны многочисленные речения Иисуса Христа - повторно открыто миру совсем недавно, в 1947 году, в ряду древних археологических находок в египетском селении Наг-Хаммади, не вызывающее никакого сомнения в его кровном родстве с каноническими источниками. Введение к этому Евангелию гласит: Это тайные слова, которье сказал Иисус жсивой и которье записал Дидим Иуда Фома. И Он сказал: Тот, кто обретет истолкование этих слов, не вкусит смерти.

Приведем некоторые выдержки из Евангелия от Фомы с краткими комментариями:

1. Иисус сказал: Пусть тот, кто иццет, не перестанет искать до тех пор, пока не найдет, и, когда найдет, он будет потрясен, и, если он потрясен, он будет удивлен, и он будет царствовать над всем.

Здесь речь идет об акте рождения в Духе, об акте рождения психического существа (души). Эти слова Иисуса удивительно точно передают незабываемую гамму ощущений, связанных с рождением в Духе. Акт раскрытия Божественного присутствия в человеке невозможно спутать с чем-либо другим.

24. Мария сказала Иисусу: на кого похожс Твоч ученики? Он сказал: Они похожси на детей мальх, которые расположились на поле, им не принадлежащем. Когда придут хозяева поля, они скажут: Оставъте нам наие поле. Они обнажсантся перед ними, чтобъ оставить это им и дать им nоле.

Иисус уподобляет Своих учеников неразумным детям, не постигшим мудрости Его слов, но считающих себя знающими. Однако знание их поверхностно и зыбко, а потому в любой момент их можно смутить, заставить сомневаться и свернуть с выбранного пути.

\footnotetext{
19 Клюев А.В. Апокриф от Иисуса, или новое прочтение Но-
} вого Завета. М.: Пилигрим-Пресс, 2007. 288 с. 
Вместе с тем Иисус не отрицает возможности со временем внесения корректив в отражение учениками Его Учения. Что и делает автор постановкой вопроса о необходимости дополнения двух источников оснований догмата третьим - прямой речью Иисуса Христа.

49. Иисус сказал: Тот, кто въсказал хулу на Отца, - ему проститься, и тот, кто высказал хулу на Сына, - ему проститься. Но тот, кто въсказал хулу на Духа Святого, - ему не проститься ни на Земле, ни на Небе.

Здесь говорится о троичности Бога и о приоритетности Его ипостасей. Наивысшей ипостасью является Дух Святой. По научно-богословским изысканиям автора Дух Святой (Творец) в бинарной оппозиции: Бог-Отец - Сын Божий является принципом дополнительности (системообразующим и управляющим фактором, «генерирующим центром»), несущим информацию о двух других ипостасях Святой Троицы.

52. Иисус сказал: Невозможно человеку сесть на двух коней, натянуть два лука, $и$ невозможно рабу служить двум господам: или он будет почитать одного и другому будет грубитъ. Ни один человек, который пьет старое вино, тотчас не стремиться въ-пить вино молодое. И не наливают молодое вино в старые мехи, дабы они не испортили его. Не накладывают старую заплату на новую одежду, ибо произойдет разрыв.

Все эти высказывания Иисуса речены Им с целью показать ученикам, что все принципиально новое не может содержать в себе определяющие элементы старого и уж тем более иметь старую основу, ибо тогда это новое окажется несостоятельным, нежизнеспособным. Новое - это заповеди Нового Завета, данные Иисусом. Старое - это Ветхий Завет, который должен быть превзойден. Или-или - или ты в смертном прошлом, или обретешь Жизнь Вечную.

Из этой установки Иисуса Христа следуют очень важные выводы:

Во-первых, содержащиеся в канонических Евангелиях высказывания Иисуса, зачастую вырванные из общего контекста, меняют смысл речений Учителя, а, следовательно, искажают смысл Учения Христа. Выход из этого негатива требует включения Евангелия от Фомы в канон.

Во-вторых, указывает на насущную необходимость дополнения двух источников оснований догмата - третьим, содержащим прямую речь Иисуса Христа или, что тоже самое, Его Учение о Спасении через Дух Святой.

B-третьих, требуют внесения изменений в содержание Указателя Евангельских и Апостольских чтений Церковных, с таким расчетом, чтобы упор делался не на Ветхий Завет, а на Новый Завет.

56. Ученики Его сказали Ему: В какой денъ наступит покой тех, которъе мертвъ? И в какой денъ Новъй Мир приходит? Он сказал им: Тот (покой), который вы ждете, пришел, но въ не познали его.

Ученики Иисуса в который раз интересуются сроками, - когда же, наконец, придет Новый Мuр. А Новый Мир-то уже пришел. С появлением Иисуса Христа на Землю нисхождение Духа Святого на планету уже состоялось. Всем жаждущим Нового Мира необходимо открыться Ему в сердце своем и обрести Царство Божие. Иисус дал духовные заповеди, позволяющие сделать это, однако учеников Его больше заботит будущее, чем повседневная духовная работа в настоящем.

81. Иисус сказал: Я - Свет, который на всех. Я - все; все въилло из Меня и все вернулосъ ко Мне. Разруби дерево, Я - там; подними камень, и ты найдешь Меня там.

Полностью воссоединившись с Отцом Небесным посредством Духа Святого, Иисус остро, на вибрационном уровне, буквально физически ощущает Божественность Своего происхождения и единство (триединство) Всего Сущего. Именно об этом Иисус говорит Своим ученикам и именно это, следуя Его заповедям, они должны открыть в себе.

115. Иисус сказал: Небеса, как и земля, свернутся перед вами, и тот, кто живой от живого, не увидит смерти. Ибо Иисус сказал: Тот, кто нашел самого себя, -мир недостоин его.

В этом речении Иисус говорит о грядущем конце века, когда изменится Земля и Небеса, когда наш физический мир обретет иную, более тонкую просветленную материальность. Среди тех людей, которые будут на Земле в те времена, лишь обретшие свою истинную сущность, вернувшиеся к своему Божественному истоку (живые от живого), не увидят смерти и станут живым семенем нового земного человечества.

Итак, обретение третъего источника оснований догматов переводит нас из плоскостной структуры восприятия явления в объемную структуру познания сущности Учения Иисуса Христа. 


\section{Философия и культура 4(64) • 2013}

При этом объем удельной (приходящейся на одну связь) информации увеличивается в 5 раз и на смену диалектике приходит триалектика. Третий источник выступает в качестве принципа дополнительности (системообразующего и управляющего фактора). Принцип дополнительности, в зависи- мости от контекста, может иметь разные формы выражения: семантический фильтр, ЭИ-барьер, информационная граница и т.д. Однако, наиболее полное обобщение принципа дополнительности отражается в принципе Любви, провозглашенном Иисусом Христом в Нагорной проповеди.

\section{Список литературъ:}

1. Августин Аврелий. О Троице: в пятнадцати книгах против ариан. Научное издание. Краснодар: Глагол, 2004. $416 \mathrm{c.}$

2. Ареопагит Дионисий свт. Мистическое богословие. М.: Тетра, 1993.

3. Баранцев Р.Г. Становление тринитарного мышления. М.-Ижевск: НИЦ «Регулярная и хаотическая динамика», 2005. 124 с.

4. Богданов А. А. Всеобщая организационная наука. Тектология. СПб.: Издание Семенова, 1912-1929.

5. Верховский С.С. Бог и человек: Учение о Боге и богопознании в свете православия. М.: Православный Свято-Тихоновский гуманитарный университет, 2004.

6. Григорий Богослов свт. Слово 45 на Св. Пасху. Творения. Т. 1. Свято-Троицкая Сергиева Лавра, 1994.

7. Григорий Богослов свт. Творения. Т. 3. М., 1911.

8. Керн Киприан арх. Антропология св. Григория Паламы. М.: Паломник, 1996.

9. Клюев А.В. Апокриф от Иисуса, или новое прочтение Нового Завета. М.: Пилигрим-Пресс, 2007. 288 с.

10. Корень Р.В. Быть честным перед Богом. Очерки философско-богословских озарений и размышлений. Краснодар: Изд-во НКА, 2012. 256 с.

11. Корень Р.В. Теория триединых систем как методологическая основа и функциональный инструментарий фундаментальных исследований. Краснодар: Изд-во НКА. 2007. 80 с.

12. Корень Р.В. Экология медиапространства: Бравый рассудок, «медиаиблисы» и живая клетка. Краснодар: Издательство НКА, 2011. 36 с.

13. Корень Р.В. Этюды для системной культурологии (Метанауки). Краснодар: Изд-во НКА. 2008. 96 с.

14. Краснов А.М. Искажение информации в процессе познания // Рационализм и культура на пороге третьего тысячелетия: Материалы III Российского Философского конгресса. Ростов-н/Д, 2002. Т. 1. C. $54-55$.

15. Леонтьев К. Энергия и единство мира // Природа и человек («Свет»). 1997. № 1. С. 16-18.

16. Лосский В.Н. Очерки мистического богословия восточной церкви. М., 1991.

17. Протопресвитер Михаил Помазанский. Православное Догматическое богословие. М.: Издательский Совет РПЦ, 2005.

18. Россия перед Вторым пришествием (Материалы к очерку Русской эсхаталогии). Издание второе. M., 1994.

19. Сошинский С.А. Чудо в системе мироздания // Вопросы философии. 2001. № 9.

20. Таранов П.С. Мудрость трех тысячелетий. М.: АСТ, 1997. 736 с.

\section{References (transliteration):}

1. Avgustin Avreliy. O Troitse: v pyatnadtsati knigakh protiv arian. Nauchnoe izdanie. Krasnodar: Glagol, 2004. $416 \mathrm{~s}$.

2. Areopagit Dionisiy svt. Misticheskoe bogoslovie. M.: Tetra, 1993.

3. Barantsev R.G. Stanovlenie trinitarnogo myshleniya. M.-Izhevsk: NITs «Regulyarnaya i khaoticheskaya dinamika», 2005. $124 \mathrm{~s}$.

4. Bogdanov A.A. Vseobshchaya organizatsionnaya nauka. Tektologiya. SPb: Izdanie Semenova, 1912-1929.

5. Verkhovskiy S.S. Bog i chelovek: Uchenie o Boge i bogopoznanii v svete pravoslaviya. M.: Pravoslavnyy Svyato-Tikhonovskiy gumanitarnyy universitet, 2004.

6. Grigoriy Bogoslov svt. Slovo 45 na Sv. Paskhu. Tvoreniya. T. 1. Svyato-Troitskaya Sergieva Lavra, 1994.

7. Grigoriy Bogoslov svt. Tvoreniya. T. 3. M., 1911. 


\section{Философия религии}

8. Kern Kiprian arkh. Antropologiya sv. Grigoriya Palamy. M.: Palomnik, 1996.

9. Klyuev A.V. Apokrif ot Iisusa, ili novoe prochtenie Novogo Zaveta. M.: Piligrim-Press, 2007. 288 s.

10. Koren' R.V. Byt' chestnym pered Bogom. Ocherki filosofsko-bogoslovskikh ozareniy i razmyshleniy. Krasnodar: Izd-vo NKA, 2012. $256 \mathrm{~s}$.

11. Koren' R.V. Teoriya triedinykh sistem kak metodologicheskaya osnova i funktsional'nyy instrumentariy fundamental'nykh issledovaniy. Krasnodar: Izd-vo NKA, 2007. 80 s.

12. Koren' R.V. Ekologiya mediaprostranstva: Bravyy rassudok, «mediaiblisy» i zhivaya kletka. Krasnodar: Izd-vo NKA, 2011. $36 \mathrm{~s}$.

13. Koren' R.V. Etyudy dlya sistemnoy kul'turologii (Metanauki). Krasnodar: Izd-vo NKA, 2008. 96 s.

14. Krasnov A.M. Iskazhenie informatsii v protsesse poznaniya // Ratsionalizm i kul'tura na poroge tret'ego tysyacheletiya: Materialy Sh Rossiyskogo Filosofskogo kongressa. Rostov-na-Donu, 2002. T. 1. S. 54-55.

15. Leont'ev K. Energiya i edinstvo mira // Priroda i chelovek («Svet»). 1997. № 1. S. 16-18.

16. Losskiy V.N. Ocherki misticheskogo bogosloviya vostochnoy tserkvi. M., 1991.

17. Protopresviter Mikhail Pomazanskiy. Pravoslavnoe Dogmaticheskoe bogoslovie. M., Izdatel'skiy Sovet RPTs, 2005.

18. Rossiya pered Vtorym prishestviem (Materialy k ocherku Russkoy eskhatalogii). Izdanie vtoroe. M., 1994.

19. Soshinskiy S.A. Chudo v sisteme mirozdaniya // Voprosy filosofii. 2001. № 9.

20. Taranov P.S. Mudrost' trekh tysyacheletiy. M.: AST, 1997. 736 s. 